\title{
Correction to: Canine breeds associated with gastric carcinoma, metaplasia and dysplasia diagnosed by histopathology of endoscopic biopsy samples
}

\author{
Marcus Vinicius Candido ${ }^{1^{*} \mathbb{D}}$, Pernilla Syrjä2 ${ }^{2}$ Susanne Kilpinen ${ }^{1}$ and Thomas Spillmann ${ }^{1}$
}

\section{Correction to: Acta Vet Scand (2018) 60:37}

https://doi.org/10.1186/s13028-018-0392-6

Following publication of the original article [1], the authors identified an error in the numbers reported in the Gastric Carcinoma section. The correct numbers are marked in bold below:

"The Belgian Tervuren was found at much greater relative risk for being diagnosed with GC from histopathological examination of endoscopically obtained gastric biopsies $(19 ; 5.7-63.9 ; \mathrm{P}<0.0001)$ in comparison to other breeds (Fig. 2)."

\section{Author details}

${ }^{1}$ Department of Equine and Small Animal Medicine, Faculty of Veterinary Medicine, University of Helsinki, P.O. Box 57, 00014 Helsinki, Finland. ${ }^{2}$ Department of Veterinary Biosciences, Faculty of Veterinary Medicine, University of Helsinki, P.O. Box 66, 00014 Helsinki, Finland.

Published online: 29 May 2020

\section{Reference}

1. Candido MV, Syrjä P, Kilpinen S, Spillmann T. Canine breeds associated with gastric carcinoma, metaplasia and dysplasia diagnosed by histopathology of endoscopic biopsy samples. Acta Vet Scand. 2018;60:37. https ://doi.org/10.1186/s13028-018-0392-6.

\section{Publisher's Note}

Springer Nature remains neutral with regard to jurisdictional claims in published maps and institutional affiliations.

(C) The Author(s) 2020. This article is licensed under a Creative Commons Attribution 4.0 International License, which permits use, sharing, adaptation, distribution and reproduction in any medium or format, as long as you give appropriate credit to the original author(s) and the source, provide a link to the Creative Commons licence, and indicate if changes were made. The images or other third party material in this article are included in the article's Creative Commons licence, unless indicated otherwise in a credit line to the material. If material is not included in the article's Creative Commons licence and your intended use is not permitted by statutory regulation or exceeds the permitted use, you will need to obtain permission directly from the copyright holder. To view a copy of this licence, visit http://creativecommons.org/licenses/by/4.0/. The Creative Commons Public Domain Dedication waiver (http://creativecommons.org/publicdomain/zero/1.0/) applies to the data made available in this article, unless otherwise stated in a credit line to the data. 